\title{
Biochemical Response of Clarias gariepinus to Cypermethrin
}

\section{Adeyemi Olalekan*}

Department of Environmental Science, Federal University of Petroleum Resources, PMB 1221, Effurun, Nigeria

\begin{abstract}
The biochemical responses of Clarias gariepinus to cypermethrin was assessed in this study. C. gariepinus was reared in various concentrations of cypermethrin-contaminated dechlorinated water $(0,5,10,15$ and 20$) \mu \mathrm{g} / \mathrm{L}$ over a period of five days and designated A (Control), B, C, D and E respectively. The levels of protein and carbohydrate metabolites, protease, cholinesterase and cytochrome oxidase of liver and muscle of fish were assayed. The total protein (TP) level of liver and muscle of Group E decreased by $20 \%$ and $29 \%$ respectively relative to the control. Conversely, free amino acid (FAA) of liver and muscle of Group E increased by about $38 \%$ and $43 \%$ respectively compared with the control. Relative to the control, the levels of glycogen and pyruvate of tissues of the liver and muscle of Clarias gariepinus reared in contaminated water was significantly $(p<0.05)$ lower while the level of lactate in the tissues was significantly $(p<0.05)$ higher. Activity of cholinesterase of the tissues of Group $E$ animals was $1 / 3$ that of control. In contrast, protease activity of tissue of Group $\mathrm{E}$ animal was about 2 folds that of control. Cypermethrin inhibited activities of cholinesterase and cytochrome oxidase by a mechanism that inhibited oxidative metabolism of carbohydrate and shifting to protein catabolism for energy requirement. Thus it may be inferred that there is a tendency to shift the aerobic pathway to anaerobic pathway of fish respiration, to meet energy demands for the physiological and metabolic activities augmented by Cypermethrin induced stress.
\end{abstract}

Keywords: Biochemical; Cypermethrin; Clarias gariepinus; Cholinesterase; Cytochrome oxidase

\section{Introduction}

The use of pesticides has increased considerably to reduce the change caused by pests to standing crops. Among these pesticides, synthetic pyrethroids are commonly used because of their rapid biodegradability and non-persistent nature. These compounds, which frequently enter the aquatic ecosystem through agricultural run-off and spraying operations adversely, affect non-target animals such as fish [1-4].

Cypermethrin, a synthetic pyrethroid is a broad-spectrum insecticide, used extensively in households, industrial and agricultural fields [5] for control of several insect pests [6]. Due to indiscriminate use, cypermethrin makes their entrance into natural water bodies through agriculture run-off and ultimately affects the several nontarget aquatic organisms; for instance, it inhibits growth and several metabolic activities of crustaceans [7], adversely affects fish metabolism [8] and hematology [9], and thus adversely affects fish meat quality and fish population [10]. Cypermethrin is also highly toxic against freshwater snail L. accuminata and also affects both their metabolism and reproduction $[11,12]$. Cypermethrin is less toxic to mammals, birds and highly toxic to fish. Fishes are unable to metabolize the pyrethroids efficiently [13]. Cypermethrin also affects the biochemical enzyme by mode of neurotransmitters like acetylcholine (Ach) and acetyl cholinesterase (AChE) activities.

Cypermethin is widely used in Nigeria by farmers for the treatment of ectoparasitic disease and pests of maize, cotton, vegetables and sorghum. The excessive use of the pesticide has always masked its toxic effects on the aquatic environment $[14,15]$. Concentration of cypermethrin in water bodies in Nigeria could be as high as between $45 \mathrm{mg} / \mathrm{dL}$ to $63 \mathrm{mg} / \mathrm{dL}$ [14]. Residues of these toxic chemicals found in water, sediments, fish and other aquatic biota can pose a risk to organisms, to predators and to human being. Pesticides at high concentrations are known to reduce the survival, growth and reproduction of fish and produce many visible effects on fish [16].

Srivastava and Kaushik [17] reported that the pesticides accumulating in the vital organs, such as liver and muscle, cause organ dysfunction, culminating in death of fishes. Activities of certain enzymes, in fish, essential for metabolic functions are altered; Disturbance of enzyme activity in fish serves as early indicator of toxicant impact $[18,19]$. The lethal effect of cypermethrin is death which usually occurs at concentration above $60 \mu \mathrm{g} / \mathrm{L}$. In the present study, highest level of cypermethrin is $20 \mu \mathrm{g} / \mathrm{L}$ and no mortality was recorded, hence we consider the level a sub lethal level and the toxic effect a sub lethal effect. Therefore, the present work was designed to assess the toxic effect of cypermethrin on African catfish, Clarias gariepinus, and its sub lethal effects on its metabolism. Clarias gariepinus is a common, freshwater, edible fish in Nigeria and some other parts of the world due to their high nutritive food value.

\section{Materials and Methods}

Cypermethrin ([S, R]-N-a-cyno-3-phenoxybenzyl-(IR, IS, cis, trans)-2, 2-dimethyl-3, (2, 2-dichlorovinyl) cylcopropane carboxylate) manufactured by M/S Tropical Agrosystem Pvt. Ltd. Chennai, India, and purchased from local market of Udu, Delta State, Nigeria.

One hundred and fifty juvenile species of C.gariepinus with the mean weight of $61.2 \pm 4.5 \mathrm{~g}$ and standard length mean length of 15.3 $\pm 2.1 \mathrm{~cm}$ were used for the experiment. They were purchased from a reputable fish farm in Delta State, Nigeria. The fish were kept in transparent plastic tanks filled with dechlorinated tap water and made to acclimatize in laboratory conditions for two weeks. The experimental fish were managed in accordance with the guidelines for handling experimental animals. They were fed $(3 \% \mathrm{w} / \mathrm{w})$ with commercial feeds. Water quality was measured according to the method of APHA/ AWWA/WEF [20]. The temperature of the experimental water was $25.8 \pm 0.6^{\circ} \mathrm{C}$, $\mathrm{pH}$ was $7.3 \pm 0.2$ dissolved oxygen was $6.8 \pm 0.3 \mathrm{mg} / \mathrm{L}$, free carbon dioxide was $5.8 \pm 0.5 \mathrm{mg} / \mathrm{L}$ and alkalinity was $104.9 \mathrm{mg} / \mathrm{L}$. Water was changed every day.

*Corresponding author: Adeyemi Olalekan, Department of Environmental Science, Federal University of Petroleum Resources, PMB 1221, Effurun, Nigeria, Tel: +234(0)8037159452; E-mail: Adeyemi.olalekan@fupre.edu.ng

Received October 14, 2014; Accepted November 17, 2014; Published November 20, 2014

Citation: Olalekan A (2014) Biochemical Response of Clarias gariepinus to Cypermethrin. J Environ Anal Toxicol 5: 250. doi: 10.4172/2161-0525.1000250

Copyright: (c) 2014 Olalekan A, This is an open-access article distributed under the terms of the Creative Commons Attribution License, which permits unrestricted use, distribution, and reproduction in any medium, provided the original author and source are credited. 
$1 \mathrm{~g}$ of cypermethrin was dissolved into $100 \mathrm{ml}$ technical grade acetone. Five plastic aquaria $(56 \times 28 \times 28 \mathrm{~cm})$ with $30 \mathrm{~L}$ of dechlorinated water were contaminated with varying concentration of cypermethrin, and designated as follows:

A: dechlorinated tap water free of cypermethrin

B: water contaminated with $5 \mu \mathrm{g} / \mathrm{L}$ cypermethrin

$\mathrm{C}$ : water contaminated with $10 \mu \mathrm{g} / \mathrm{L}$ cypermethrin

D: water contaminated with $15 \mu \mathrm{g} / \mathrm{L}$ cypermethrin

E: water contaminated with $20 \mu \mathrm{g} / \mathrm{L}$ cypermethrin

After the period of acclimation, the fish were randomly distributed into the five plastic aquaria $(\mathrm{A}-\mathrm{E})$ ten fish per aquarium. Each of these treatments had three replicates. The control group of fish was kept in aquarium A while aquaria B-E contained the test group of fish reared in water contaminated with varying concentrations of cypermethrin. The experiment lasted for ten days.

After completion of treatment, the test animals were removed from aquaria, washed with water, and sacrificed. Afterwards, the liver and muscle tissue were quickly dissected out, freed from adipose and connective tissues and homogenized using pre-cooled pestle and mortar in a bowl of ice cubes and homogenate was used for biochemical analysis.

\section{Biochemical Analysis}

Total Protein levels were estimated according to the method of Lowry et al. [21], using bovine serum albumin as standard. Homogenates $(5 \mathrm{mg} / \mathrm{mL}, \mathrm{w} / \mathrm{v})$ were prepared in $10 \%$ Tri Chloro Acetic acid (TCA). Result was expressed as $\mu \mathrm{g} / \mathrm{mg}$.

Estimation of total free amino acid was made according to the method of Spices [22]. Homogenates $(10 \mathrm{mg} / \mathrm{mL}, \mathrm{w} / \mathrm{v})$ were prepared in $95 \%$ ethanol, centrifuged at $6000 \mathrm{xg}$ and used for amino acid estimation. Result was expressed as $\mu \mathrm{g} / \mathrm{mg}$.

Glycogen level was estimated by the method of Van der Vies [23]. Homogenate $(10 \mathrm{mg} / \mathrm{mL})$ was prepared in $5 \%$ TCA. Glucose was used as standard. Result was expressed as $\mu \mathrm{g} / \mathrm{gm}$.

Pyruvate level was estimated by the method of Friedemann and Haugen [24]. Homogenate $(50 \mathrm{mg} / \mathrm{mL})$ was prepared in $10 \%$ TCA. Sodium pyruvate was used as standard. Result was expressed as $\mu \mathrm{g} / \mathrm{mg}$.

Lactate level was estimated by the method of Huckabee [25]. Homogenate $(50 \mathrm{mg} / \mathrm{mL})$ was prepared in $10 \%$ TCA. Sodium lactate was used as standard. Result was expressed as $\mu \mathrm{g} / \mathrm{mg}$.

Protease enzyme activity was estimated by the method of Moore and Stein [26]. Homogenate $(50 \mathrm{mg} / \mathrm{mL})$ was prepared in cold distilled water. Tyrosine was used as standard. Result was expressed asumoles tyrosine/mg protein/h.

Cholinesterase (AChE) enzyme activity was estimated by the method of Ellman et al. [27]. Homogenate $(50 \mathrm{mg} / \mathrm{mL})$ was prepared in $0.1 \mathrm{M}$ phosphate buffer, $\mathrm{pH} 8.0$, for $5 \mathrm{~min}$ in an ice bath. Homogenate was centrifuged at $1000 \mathrm{~g}$ for $30 \mathrm{~min}$ at $-4^{\circ} \mathrm{C}$. The enzyme containing supernatant $(0.05 \mathrm{ml})$ was pipetted to a cuvette. To this was added $5 \times 10$ $4 \mathrm{M}$ of freshly prepared acetylcholine iodide solution in distilled water as substrate, $1.45 \mathrm{ml}$ of buffer ( $\mathrm{pH} 8.0$ ) and $0.05 \mathrm{ml}$ of chromogenic agents, 5:5 dithio-bisnitrobenzoate (DTNB). The change in optical density at $412 \mathrm{~nm}$ caused by the enzymatic reaction, was monitored for $3 \mathrm{~min}$ at $25^{\circ} \mathrm{C}$. Glutathionine was used as standard. Result was expressed as $\mu \mathrm{mol}$ “SH”hydrolysed/min/mg protein.

Cytochrome Oxidase ( $\mathrm{CyO})$ enzyme activity was estimated by the method of Cooperstein and Lazarow [28]. Homogenate $(50 \mathrm{mg} / \mathrm{mL})$ was prepared in $0.33 \mathrm{M}$ phosphate buffer, $\mathrm{pH} 7.4$, for $5 \mathrm{~min}$ in ice bath. Cytochrome-C was used as standard. Result was expressed as arbitrary units/min/mg proteins.

\section{Statistical Analysis}

The statistical analysis of data was done using SPSS11.5; Mean \pm SEM. Post-hoc comparison using Duncan's New Multiple Range Test (DNMRT) was employed. DNMRT is a One-Way Analysis of Variance (ANOVA) that allows multiple comparisons. The error rate of each pairwise comparison is considered rather than an overall rate, and allows a higher rate for pairs of sample averages that are further apart when ordered by size. The significance of the test result was observed at $\mathrm{P}<0.05$ level.

\section{Results}

The levels of total protein (TP) and free amino acids (FAA) of liver of Clarias gariepinus reared in water contaminated with various concentration of cypermethrin is shown in Table 1. Relative to the control, the level of TP of liver and muscle of C. gariepinus reared in contaminated water was significantly $(\mathrm{p}<0.05)$ lower. The significant reduction of TP was most profound at highest concentration of cypermethrin $(20 \mu \mathrm{g} / \mathrm{L})$. Specifically, the reduction in TP level was about $20 \%$ and $29 \%$ in the liver and muscle respectively. Conversely, FAA of liver and muscle of test animals was significantly $(p<0.05)$ than that of control. The increase was about $38 \%$ and $43 \%$ in the liver and muscle of Group E animals respectively relative to the control.

Relative to the control, the levels of glycogen and pyruvate of tissues of the liver and muscle of Clarias gariepinus reared in contaminated water was significantly $(p<0.05)$ lower while the level of lactate in the tissues was significantly $(\mathrm{p}<0.05)$ higher. This significant difference was observed to widen as the concentration of cypermethrin increased. The level of lactate of liver and muscle of Group E was 2 folds and 1 1/2 folds respectively, compared with that of control. The observations are shown in Table 2.

Table 3 presents the effect of cypermethrin on the specific activities of protease, cholinesterase and cytochrome oxidase of tissues of C. gariepinus. Generally, the activities of the cholinesterase and cytochrome oxidase decreased significantly $(\mathrm{p}<0.05)$ in the tissues of the test animals relative to the control. Activity of cholinesterase of the tissues of Group E animals was 1/3 that of control. In contrast, protease activity of tissues of test animals was significantly $(\mathrm{p}<0.05)$ higher than control. Protease activity of tissue of Group E animal was about 2 folds that of control.

Table 1: Effect of cypermethrin on level $(\mu \mathrm{g} / \mathrm{mg})$ of total protein (TP) levels and free amino acids (FAA) of the liver and muscle of Clarias gariepinus

\begin{tabular}{|c|c|c|c|c|}
\hline \multirow[b]{2}{*}{ Group } & \multicolumn{2}{|c|}{ Total protein } & \multicolumn{2}{|c|}{ Free amino acid } \\
\hline & Liver & Muscle & Liver & Muscle \\
\hline A (Control) & $125.4 \pm 1.24^{a}$ & $136.7 \pm 0.89^{a}$ & $14.8 \pm 0.43^{a}$ & $27.2 \pm 0.78^{a}$ \\
\hline B (5 g/L Cypermethrin) & $119.2 \pm 0.98^{b}$ & $125.5 \pm 1.12^{b}$ & $16.4 \pm 0.14^{b}$ & $30.3 \pm 0.65^{b}$ \\
\hline $\begin{array}{c}\mathrm{C}(10 \mu \mathrm{g} / \mathrm{L} \\
\text { Cypermethrin) }\end{array}$ & $114.8 \pm 1.07^{c}$ & $118.3 \pm 0.94^{c}$ & $17.6 \pm 0.22^{c}$ & $34.6 \pm 0.56^{c}$ \\
\hline $\begin{array}{c}\mathrm{D}(15 \mu \mathrm{g} / \mathrm{L} \\
\text { Cypermethrin) }\end{array}$ & $108.9 \pm 1.04^{d}$ & $106.4 \pm 1.02^{\mathrm{d}}$ & $19.2 \pm 0.76^{\mathrm{d}}$ & $36.7 \pm 0.37^{d}$ \\
\hline 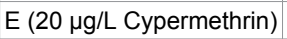 & $100.2 \pm 1.11^{\mathrm{e}}$ & $96.8 \pm 1.01^{e}$ & $20.5 \pm 0.53^{e}$ & $38.9 \pm 0.44^{e}$ \\
\hline
\end{tabular}

Values are means \pm SEM for 10 determinationss. ${ }^{a, b, c}$ Column values with different superscripts are significantly different $(p<0.05)$. 
Table 2: Effect of cypermethrin on level $(\mu \mathrm{g} / \mathrm{mg})$ of glycogen, pyruvate and lactate of the liver and muscle of the liver and muscle of Clarias gariepinus

\begin{tabular}{|c|c|c|c|c|c|c|}
\hline \multirow[b]{2}{*}{ Group } & \multicolumn{2}{|c|}{ Glycogen } & \multicolumn{2}{|c|}{ Pyruvate } & \multicolumn{2}{|c|}{ Lactate } \\
\hline & Liver & Muscle & Liver & Muscle & Liver & Muscle \\
\hline $\begin{array}{c}\text { A } \\
\text { (Control) }\end{array}$ & $\begin{array}{c}3.05 \pm \\
0.08^{a}\end{array}$ & $\begin{array}{c}2.57 \pm \\
0.07^{\mathrm{a}}\end{array}$ & $\begin{array}{c}2.88 \pm \\
0.05^{a}\end{array}$ & $\begin{array}{c}1.69 \pm \\
0.04^{a}\end{array}$ & $\begin{array}{c}2.50 \pm \\
0.13^{a}\end{array}$ & $\begin{array}{c}2.27 \pm \\
0.10^{\mathrm{a}}\end{array}$ \\
\hline B & $\begin{array}{c}2.65 \pm \\
0.06^{b}\end{array}$ & $\begin{array}{c}2.19 \pm \\
0.05^{b}\end{array}$ & $\begin{array}{c}2.50 \pm \\
0.09^{b}\end{array}$ & $\begin{array}{c}1.45 \pm \\
0.04^{\mathrm{b}}\end{array}$ & $\begin{array}{c}3.67 \pm \\
0.09^{b}\end{array}$ & $\begin{array}{c}3.05 \pm \\
0.07^{b}\end{array}$ \\
\hline C & $\begin{array}{c}2.57 \pm \\
0.07^{c}\end{array}$ & $\begin{array}{c}1.99 \pm \\
0.06^{c}\end{array}$ & $\begin{array}{c}2.28 \pm \\
0.04^{c}\end{array}$ & $\begin{array}{c}1.27 \pm \\
0.03^{c}\end{array}$ & $\begin{array}{c}4.45 \pm \\
0.12^{\mathrm{c}}\end{array}$ & $\begin{array}{c}3.49 \pm \\
0.08^{\mathrm{c}}\end{array}$ \\
\hline$D$ & $\begin{array}{c}2.34 \pm \\
0.04^{d}\end{array}$ & $\begin{array}{c}1.78 \pm \\
0.04^{d}\end{array}$ & $\begin{array}{l}1.99 \pm \\
0.03^{d}\end{array}$ & $\begin{array}{c}1.05 \pm \\
0.04^{d}\end{array}$ & $\begin{array}{c}4.89 \pm \\
0.11^{\mathrm{d}}\end{array}$ & $\begin{array}{c}3.85 \pm \\
0.06^{d}\end{array}$ \\
\hline $\mathrm{E}$ & $\begin{array}{c}2.06 \pm \\
0.03^{\mathrm{e}}\end{array}$ & $\begin{array}{c}1.65 \pm \\
0.04^{\mathrm{e}}\end{array}$ & $\begin{array}{c}1.87 \pm \\
0.01^{\mathrm{e}}\end{array}$ & $\begin{array}{c}0.98 \pm \\
0.03^{\mathrm{e}}\end{array}$ & $\begin{array}{c}5.01 \pm \\
0.08^{\mathrm{e}}\end{array}$ & $\begin{array}{c}4.02 \pm \\
0.05^{\mathrm{e}}\end{array}$ \\
\hline
\end{tabular}

Values are means \pm SEM for 10 determinationss. ${ }^{a, b, c}$ Column values with different superscripts are significantly different $(p<0.05)$.

Table 3: Effect of cypermethrin on specific activities of protease, acetylcholinesterase and cytochrome oxidase of the liver and muscle of the liver and muscle of Clarias gariepinus

\begin{tabular}{|c|c|c|c|c|c|c|}
\hline \multirow[b]{2}{*}{ Group } & \multicolumn{2}{|c|}{$\begin{array}{c}\text { Protease }(\mu \text { moles } \\
\text { tyrosine } / \mathrm{mg} \\
\text { protein } / \mathrm{h})\end{array}$} & \multicolumn{2}{|c|}{$\begin{array}{c}\text { Acetylcholinesterase } \\
\text { ( } \mu \mathrm{mol} \text { "SH"hydrolysed/ } \\
\mathrm{min} / \mathrm{mg} \text { protein) }\end{array}$} & \multicolumn{2}{|c|}{$\begin{array}{l}\text { Cytochrome } \\
\text { oxidase (units/min/ } \\
\text { mg Proteins) }\end{array}$} \\
\hline & Liver & Muscle & Liver & Muscle & Liver & Muscle \\
\hline $\begin{array}{c}\text { A } \\
\text { (Control) }\end{array}$ & $\begin{array}{c}0.74 \pm \\
0.02^{\mathrm{a}}\end{array}$ & $\begin{array}{c}0.53 \pm \\
0.01^{\mathrm{a}}\end{array}$ & $\begin{array}{c}0.27 \pm \\
0.01^{\mathrm{a}}\end{array}$ & & $\begin{array}{c}57.3 \pm \\
1.74^{a}\end{array}$ & $\begin{array}{c}53.4 \pm \\
1.07^{\mathrm{a}}\end{array}$ \\
\hline B & $\begin{array}{l}0.82 \pm \\
0.02^{b}\end{array}$ & $\begin{array}{c}0.67 \pm \\
0.02^{\mathrm{b}}\end{array}$ & $\begin{array}{c}0.22 \pm \\
0.01^{\mathrm{b}}\end{array}$ & $\begin{array}{l}0.27 \pm \\
0.01^{\mathrm{b}}\end{array}$ & & $\begin{array}{c}45.2 \pm \\
1.05^{b}\end{array}$ \\
\hline C & $\begin{array}{c}0.96 \pm \\
0.04^{c}\end{array}$ & $\begin{array}{c}0.78 \pm \\
0.03^{c}\end{array}$ & $\begin{array}{c}0.19 \pm \\
0.02^{c}\end{array}$ & $\begin{array}{c}0.22 \pm \\
0.02^{\mathrm{c}}\end{array}$ & $\begin{array}{r}43.2 \pm \\
1.47^{\circ}\end{array}$ & $\begin{array}{c}40.8 \pm \\
0.29^{c}\end{array}$ \\
\hline D & $\begin{array}{l}1.04 \pm \\
0.03^{d}\end{array}$ & $\begin{array}{c}0.88 \pm \\
0.03^{d}\end{array}$ & $\begin{array}{l}0.14 \pm \\
0.01^{d}\end{array}$ & $\begin{array}{l}0.17 \pm \\
0.01^{d}\end{array}$ & $\begin{array}{c}42.4 \pm \\
1.44^{\mathrm{d}}\end{array}$ & $\begin{array}{c}38.9 \pm \\
0.34^{d}\end{array}$ \\
\hline$E$ & $\begin{array}{l}1.09 \pm \\
0.03^{e}\end{array}$ & $\begin{array}{c}0.94 \pm \\
0.02^{\mathrm{e}}\end{array}$ & $\begin{array}{l}0.09 \pm \\
0.02^{\mathrm{e}}\end{array}$ & $0.12 \pm 0.01^{\mathrm{e}}$ & $\begin{array}{c}40.7 \pm \\
1.28^{\mathrm{e}}\end{array}$ & $\begin{array}{c}37.3 \pm \\
0.52^{\mathrm{e}}\end{array}$ \\
\hline
\end{tabular}

Values are means \pm SEM for 10 determinationss. ${ }^{a, b, c}$ Column values with different superscripts are significantly different $(p<0.05)$.

\section{Discussion}

The application of environmental toxicology studies on nonmammalian vertebrates is rapidly expanding, and for aquatic system, fish have become indicators for the evaluation of the effects of noxious compounds. This study presents the first report on metabolites and key enzymes of neurotransmission and electron transfer of the tissues of C. gariepinus reared in cypermethrin contaminated water.

The reduced level of total protein (TP) and elevated level of free amino acid (FAA) in the tissues of C. gariepinus reared in cypermethrincontaminated water (B-E) revealed protein breakdown to amino acids (Table 1). It also suggests impaired incorporation of amino acids in protein synthesis and decline in nucleic acid level [29].

Decreased glycogen and pyruvate levels and increased level of lactate in the tissues of C. gariepinus reared in cypermethrin-contaminated water is suggestive of impairment of oxidative metabolism (Table 2). Cypermethrin had been reported to induce stress condition resulting in less availability of oxygen, which in turn led to less ATP production in tissues and thus adversely affecting oxidative metabolism [30]. Fishes needed more energy to detoxify toxicants and to overcome stress induced by the toxicants. Carbohydrates are the primary and immediate source of energy. In stress condition, there is depleting in the carbohydrates reserve to meet energy demand. Depletion of glycogen may be due to its direct utilization for energy generation, a demand caused by cypermethrin induced hypoxia [12]. The level of tissue lactate content acts as an index of anaerobiosis, which might be beneficial for animal to bear hypoxic condition whereas pyruvate level in tissue can be taken as a measure of aerobic condition. In this study, with increased lactate content, there was a decreased pyruvate content, which suggests a shift towards anaerobiosis as a consequence of hypoxia, leading to respiratory distress [31]. The lactic acid accumulation in muscle is an augmentation of glycolytic pathway as a consequence of stress. The decreased pyruvate level may be due to its conversion to lactate or due to its mobilization to form amino acids, lipids, and so other metabolites in addition to its role as a detoxification factor [31]. The decrease in protein level in liver and muscle tissues (Table 1) may be a result of trying to meet higher energy demands for metabolic purposes.

The increased protease activity (Table 3 ) may be responsible for the decreased in total protein level and increased total free amino acid level observed in Table 2.

Animal behaviour is usually regulated by neurosecretion such as acetylcholinesterase (AChE) at the synapse [31]. From experimental data, it is evident that cypermethrin inhibits activity of enzyme cholinestrase (ChE) (Table 3). ChE activity inhibition is well known as a biomarker indicating the effect of neurotoxic substances). This will result in tumors, convulsions and finally the death of the aquatic organism. The inhibition of cholinesterase (ChE) activity in fish can be dangerous since it will affect feeding capability, swimming activity, identification, avoidance of predators and spatial orientation of the species. Decreased cholinesterase (ChE) activity decreases the cellular metabolism, induces deformities of cell membrane, and disturbs metabolic and nervous activity [31]. Cypermethrin acts as neuroactive poisons, interfering with the nerve impulse conduction and changes the nerve membrane permeability.

Cytochrome oxidase transfers electrons to their final acceptor, oxygen, in electron transport chain (ETC). It produces ATP molecules thereby influencing other cellular metabolic process. In this study, cypermethrin caused a decrease in cytochrome oxidase activity in liver and muscle tissues, with a profound impact on the oxidative metabolism [31]. Decrease in cytochrome oxidase activity could either be due to reduced availability of oxygen, which in turn has reduced the capacity of the ETC to produce ATP molecules, or because after metabolism of cypermethrin, cyano group separated and attached with metal ion $(\mathrm{Fe}, \mathrm{Cu})$ present in cytochrome oxidase enzyme and reduced their activity [32].

\section{Conclusion}

Experimental evidence from the present study revealed that cypermethrin affects biochemistry of $\mathrm{C}$. gariepinus by a mechanism that adversely affects oxidative metabolism shifting the respiratory pathway of fish towards anaerobic pathway thereby inhibiting energy production by suppressing ATP synthesis. Application of cypermethrin should be done with great care to avoid contamination of water bodies and to maintain healthy aquatic lives. Future research should consider toxicology of contaminated fish on consumers.

\section{Acknowledgement}

The author acknowledges Prof O.B Oloyede and Prof (Mrs) A.T. Oladiji, Department of Biochemistry, University of Ilorin, for their assistance.

\section{References}

1. Murphy SD (1966) Liver metabolism and toxicity of thiophosphate insecticides in mammalian, avian and piscine species. Proc Soc Exp Biol Med 123: 392-398.

2. Ansari BA, Kumar K (1984) Malathion toxicity: in vivo inhibition of acetylcholinesterase in the fish Brachydanio rerio (Cyprinidae). Toxicol Lett 20: 283-287. 
3. Singh SK, Tripathi PK, Yadav RP, Singh D, Singh A (2004) Toxicity of malathion and carbaryl pesticides: effects on some biochemical profiles of the freshwater fish Colisa fasciatus. Bull Environ Contam Toxicol 72: 592-599.

4. Shailendra KS, Sunil KS, Ram PY (2010) Toxicological and Biochemical Alterations of Cypermethrin (Synthetic Pyrethroids) Against Freshwater Teleost Fish Colisa fasciatusat Different Season. World J Zool 5: 25-32

5. Kakko I, Toimela T, Tähti H (2003) The synaptosomal membrane bound ATPase as a target for the neurotoxic effects of pyrethroids, permethrin and cypermethrin. Chemosphere 51: 475-480.

6. Yilmaz M, Gül A, Erbaşli K (2004) Acute toxicity of alpha-cypermethrin to guppy (Poecilia reticulata, Pallas, 1859). Chemosphere 56: 381-385

7. Li X, Ping X, Xiumei S, Zhenbin W, Liqiang X (2005) Toxicity of cypermethrin on growth, pigments, and superoxide dismutase of Scenedesmus obliquus. Ecotoxicol Environ Saf 60: 188-192.

8. Polat H, Erkoç FU, Viran R, Koçak O (2002) Investigation of acute toxicity of beta-cypermethrin on guppies Poecilia reticulata. Chemosphere 49: 39-44

9. Adhikari S, Sarkar B, Chatterjee A, Mahapatra CT, Ayyappan S (2004) Effects of cypermethrin and carbofuran on certain hematological parameters and prediction of their recovery in a freshwater teleost, Labeo rohita (Hamilton). Ecotoxicol Environ Saf 58: 220-226.

10. Cullen MC, Connell DW (1992) Bioaccumulation of chlorohydrocarbon pesticides by fish in the natural environment. Chemosphere 25: 1579-1587.

11. Singh A, Agarwal RA (1990) Molluscicidal properties of synthetic pyrethroids. Journal of Medicinal and Applied Malacology 2: 141-144.

12. Tripathi PK, Singh A (2004) Toxic effects of cypermethrin and alphamethrin on reproduction and oxidative metabolism of the freshwater snail, Lymnaea acuminata. Ecotoxicol Environ Saf 58: 238-243.

13. Meenambal M, Pugazhendy K, Vasantharaja C, Venkatesan S, Jayachandran K (2012) Attenuating Property of Delonix elata Plant Against Inhibition of Acetylcholinesterase Due to Cypermethrin Toxicity on Fresh Water Fish Cyprinus carpio (Linn). International Journal of Pharmaceutical \& Biological Archive 3: 654-658

14. Osibanjo O, Bamigbose O (1990) Chlorinated hydrocarbons in marine fish and shellfish of Nigeria. Marine pollution Bulletin 21:581-586.

15. Olaruntuyi O, Mulero O, Odunkale B (1992) Histopathology of O.niloticus exposed to Actellic $25 \mathrm{EC}$. Journal of Aquatic Science 6:13-17.

16. Rahman MZ, Hossain Z, Mellah MFA Ahmed GU (2002) Effect of diazinon $60 E C$ on Anabus testudineus, channa punctatus and Barbades gomonotus Naga. AQUABYTE.

17. Srivastava N, Kaushik N (2001) Use of fish as bioindicator of aquatic pollution," in Proceedings of the International Congress of Chemistry and Environment. SL Gargh Ed 227-229 Indore, India.
18. Jensen EG, Skaare JU, Egaas E, Goksoyr A (1991) Response of xenobiotic metabolizing enzymes in rainbow trout (Oncorhynchus mykiss) to endosulfan detected by enzyme activities and immunochemical methods. Aquatic Toxicology 21: 81-92.

19. Adeyemi O, Adeyemi O, Osubor CC (2009) Effect of Clarias gariepinus cultured in contaminated water on rats. Hum Exp Toxicol 28: 759-764.

20. APHA/AWWA/WEF (1998) Standard Methods for the Examination of Water and Wastewater, American Public Health Association, New York, USA 20th edition.

21. Lowry OH, Rosebrough NJ, Farr AL, Randall RJ (1951) Protein measurement with the Folin phenol reagent. J Biol Chem 193: 265-275.

22. Spices JR (1957) Colorimetric procedures for amino acids. In Methods of Enzymology, Calowick SP, Kaplon NO (Eds) 468, Academic Press, New York, USA.

23. Van der vies $\mathrm{J}$ (1954) Two methods for the determination of glycogen in liver. Biochem J 57: 410-416.

24. Friedemann TE, Haugen GF (1942) Pyruvic acid: I. Collection of blood for the determination of Pyruvic acid and lactic acid. J Biol Chem 144: 67-77.

25. Huckabee WE (1961) Blood analysis, determination of lactic acid. In Hawk's Physiological Chemistry Oser BL (Ed) 1103, Tata McGraw-Hill, New Delhi India, 14th edition.

26. Moore S, Stein WH (1954) A modified ninhydrin reagent for the photometric determination of amino acids and related compounds. J Biol Chem 211 907-913.

27. Ellman GL, Courtney KD, Andres V Jr, Feather-stone RM (1961) A new and rapid colorimetric determination of acetylcholinesterase activity. Biochem Pharmacol 7: 88-95.

28. Cooperstein SJ, Lazarow A (1951) A microspectrophotometric method for the determination of cytochrome oxidase. J Biol Chem 189: 665-670.

29. Bhavan PS, Geraldine P (2001) Biochemical stress responses in tissues of the prawnMacrobrachium malcolmsoniion exposure to endosulfan. Pesticide Biochemistry and Physiology 70: 27-41.

30. Tripathi PK, Singh A (2004) Toxic effects of cypermethrin and alphamethrin on reproduction and oxidative metabolism of the freshwater snail, Lymnaea acuminata. Ecotoxicol Environ Saf 58: 227-235.

31. Tiwari S, Tiwari R, Singh A (2012) Impact of cypermethrin on fingerlings of common edible carp (Labeo rohita). ScientificWorldJournal 2012: 291395.

32. Corbett JR, Wright K, Bailee AC (1984) Pesticides interfering with respiration. In The Biochemical Mode of Action of Pesticides, Corbett JR, Wright K, Bailee AC (Eds) Academic Press, London, UK 1-49. 